\title{
Indonesia Politics in Eradicating Inequalities in The Border Area
}

\author{
Widya Setiabudi Sumadinata ${ }^{1}$, Rizki Ananda Ramadhan ${ }^{1, *}$ \\ ${ }^{1}$ Department of International Relations, Universitas Padjadjaran, J1. Raya Bandung Sumedang KM 21Jatinangor 45363
}

\begin{abstract}
Inequalities is inherent characteristic in dealing with border development. As a large archipelagic country, Indonesia still has so many homeworks in managing border areas. For years border areas have been marginalized from national development process. The inequalities could be seen in several aspects, such as a low level of public services availability; low quality and access of education; bad economic condition and high level of poverty. The scope of this paper is to explore some changes in Indonesian border management and development under Joko Widodo's administration, especially the efforts to eradicate inequalities. The method used in the research is qualitative approach through literature review and interviews. The result of this paper shows that Indonesian government under Joko Widodo's presidency has done some important policies to bring the social justice in border areas. However, they still have to encounter very substantial challenges and obstacles such as the problems of institutional and human resource capacity. Joko Widodo shows a very strong commitment to build border areas as good as other areas in Indonesia.
\end{abstract}

Keywords: Inequalities; Border Management; Public Services; Society; Nationalism; Public Policy

\section{Introduction}

Most countries still invest their sovereignty in territoriality concern, including Indonesia. Thus, border area management is always related with national security issues. Furthermore, from legal aspects, border areas determine the scope of applicability of national law of a country. While politically, the border region is the end of the supreme authority of a state over the territory and everything within the territory. Therefore, border areas management have a direct connection with the implementation of development, social welfare and national defense. Nevertheless, since independent day until reformation era Indonesian border areas have always been left behind.

People in border areas have had limited access to almost every aspect of life. They have to pay more expensive for basic commodities such as foods and clothes. The problem of scarcity and price disparities for fuel, electricity and construction material have directly obstructed the development. Inequalities is getting worse and worse while other part of this countries enjoying the benefits of development. Those conditions have driven people to take illegal trans-border activities for economic survival reasons. Smuggling and trafficking have been a part of daily life in some Indonesian border areas.

At the regional level, Southeast Asia have several ongoing territorial disputes[1]. On one hand, the security issues in border are simply inevitable. On the other hand, this region also has a vast and dynamic progress both international and transnational relations. For example, Indonesia-Malaysia territorial disputes encompass both national security issues and transnational relations among citizens in border area[2].

Almost all border areas of Indonesia is least developed region comparing to other areas, particularly Java Island. National Security as dominant approach has been performed for almost 70 years in managing border areas. Soeharto regime put the border and sovereignty notions in "Wawasan Nusantara" concept as a part of civic education. The concept was too broad and just served as national doctrine without any further implementation in real policy regarding border management. Ironically, with the strong military background Soeharto showed even a little attention in providing appropriate military facilities in the border areas.

In 2010, Susilo Bambang Yudhoyono's Administration start to put some considerations on socioeconomic, socio-cultural approaches, and also socioenvironmental. For those reasons, government established the National Agency for Border Management (Badan Nasional Pengelola Perbatasan/BNPP) to accelerate the development in border areas. This government efforts such as development on economic, industrialisation, and local environment. This effort aim to maintain and synergy between industrialisation and natural environment.

\section{Methodology}

This paper presents the results based on qualitative research conducted from April to October 2017. The in-

*Corresponding author: rizkiar@hotmail.com 
depth interviews has been done with the representatives from BNPP and the Sumba Barat Daya local government as an outer island border region. The research also applied document and literature reviews to get more comprehensive data in exploring Joko Widodo's policies regarding border management and development.

\section{Discussion}

The state responsibility is always presupposed in the concept of border to claim their sovereignty. The state has to protect its border and everything within. It also has to fulfil the needs of its citizen, especially the security and welfare[3]. Therefore, the government has to provide the policy and supporting institutions to manage its responsibilities to the citizen. In this context, BNPP will be expected as institution in fulfilling the rights of citizen who live in border areas.

In accordance with Law No.43 (2008), in the updated Presidential Decree No.12 (2010), BNPP's duties are including: formulating policies, formulating budget use plans, coordinating implementation, and evaluating. In the development activities, but the nature of initiate and stimulate, for the next relevant ministry in cooperation with various parties who will run it[2]. BNPP also encourages community empowerment through various activities managed by related agencies. Assistance and trainings to improve the management, skills to process leading commodities in the region, such as agriculture and livestock. Yet, the agency had not performed effectively until the end of SBY presidency. Some perspectives said that SBY still had a conservative paradigm to see the border areas as backyard than a facade.

Contemporary security approaches have been shifting, human security has become very important discourse. Non-military threats are recognized to be one of the problems at the border areas[4]. Poverty is the main trigger for the emergence of transnational crime. One of the biggest challenges in managing border development is to get rid the economic injustice. Inequalities will create a vulnerable society to human security issues.

Joko Widodo's administration through Nawacita has a great concern to shift the development paradigm on the border. So that development activity on the border is more dynamic than before. BNPP mapped some of the main issues on the border: human trafficking, illegal logging, or other activities on the border still exist. Efforts made including the construction of more representative the seven cross-border gates (Pos Lintas Batas Negara/PBLN). PBLNs is expected to prevent and reduce illegal activities at the border, especially related to transnational crime. The border development has been designed gradually by setting target and priorities. Government has created specific priority region (lokasi prioritas/lokpri) to achieve the targets more effectively. Furthermore, BNPP has set the criteria determining priority location 2010-2014 as follows[5]: (1) Sub-districts that border directly with neighboring countries and / or there exit / entry point (on land); (2) Sub-districts that traditionally have intensive interaction from the social, cultural, and economic side with neighboring neighboring residents (marked by exit / entry point by sea agreed with neighboring country); (3) Sub-districts designated as National Strategic Activities Center (PKSN); (4) Subdistricts with the Smallest Outlying Islands (PPKT); and (5) Special consideration.

The priority location was selected by identifying the potentials, challenges and obstacles in concern with geopolitics, geo-economics and socio-cultural characteristics. Since the escalation of South China Sea disputes and considering the most occupied international trade traffics, the government has chosen more border areas in north side such as Natuna Islands, Kalimantan's border areas as priority locations.

The government has started a positive attitude to see the border areas as important facades. They also aware that socio-cultural aspect has played important roles in shaping the characteristics of each particular areas. It is important to understand that every border area also has their own problems. Martinez views provide the type of society on the border. The people on the border are divided into national border-landers and transnational borderlanders. The difference between these two types is in the way they address the existence of neighbours (in the context of the country)[6]. In the type of national borderlanders, they tend to have a low level of interaction with the economic and cultural influences of neighbouring people; the outer island such as Sumba can be seen an example. While the transnational border-landers type is a society that is influenced by foreign economy or culture and maintains contact with neighbouring country people even visiting, shopping, working, studying or living in a period of time which is not fixed in neighbouring countries, for instance Indonesia-Malaysia border areas in Kalimantan. From this point of view, development and community empowerment are being inseparable. Community empowerment is usually related to local culture or wisdom. From BNPP experienced, there are some local values that in the beginning become barrier, but in the end can be used as means in strengthening the development program. Each border areas has its own characteristics. Potential resources include natural resources and social or human resources.

The government has been emphasizing to increase economic growth in border areas after five of the seven PLBNs had inaugurated by the President. It is important to provide the sufficient physical infrastructures in accommodating socio-economic activities to accelerate the development in border areas. However, human resources are key actors to make everything work well. Human resources can play a role in processing potentials into some added values. Infrastructure and Human Resource Development should be aligned to optimize the benefits. BNPP also affirms that the government recognizes the importance of non-governmental 
institution roles in the context of community empowerment and development at the border. There are efforts to establish cooperation and networking among government, NGOs and community groups the border areas, including local community leaders who are often very helpful in resolving various obstacles and horizontal conflicts. The current border development paradigm is an affirmative policy that is oriented towards the immediate needs of society and is not oriented towards government revenues, in contrast to non-border areas that still consider the profit aspect. Short-term development on the border will be seen not to have a direct impact, but in the long run will bring gradual impacts through the positive activities that generate multiple effects.

According to Bappenas and media reports[7], inequalities in public services and social welfare in the Indonesian border area are mostly caused by following factors: (1) The past policies with non-comprehensive and centralized approaches; (2) For almost seven decades the border issue has not received enough attention from the government. This is reflected in development policies that lack attention to border areas and always focused on densely populated areas with easy access. While for remote, isolated and under-developed areas such as border areas are still not prioritized, in spite of their extraordinary economic contribution like Papua; (3) The decentralization processes have not run effectively as expected; and (4) Over the years as inequalities have kept growing, many people in border areas become more dependent with various facilities from neighbouring countries and creates low engagement with nationalism.

Border development policy has finally changed when President Joko Widodo took over the administration by setting a vision of Nawacita's mission. The border development is stated as a third priority program that government will build Indonesia from the periphery by strengthening districts and villages as most important part of national integrity and sovereignty. The maritime vision also confirms government commitment to give more actual support for border areas. Some positive impacts have been already enjoyed such as eliminating high price disparities on fuels[8] and other commodities through a new distribution system called Tol Laut[9]. New airports and seaports has been built to establish better connectivity.

This research also take Southwest Sumba as nonpriority sample. As one of the districts that in outermost point location, Southwest Sumba becomes very important regarding national integrity and sovereignty. From the data and interviews with local government and communities, they are all confirming that the attention to this region began more intensive since the reign of President Joko Widodo. In the context of national defense, there has been realization as well as planning to strengthen it. Sustained and strong commitment is required, especially from the central government, to accelerate adequate infrastructure development in this area.
Southwest Sumba has not yet entered the priority location either from Ministry of Defense or BNPP data. Nevertheless, the development commitment is directly conveyed by President Joko Widodo through his visits to this region. This is expected to be a signal to make the East Nusa Tenggara region especially Sumba Island which has been very marginalized in development can be considered as a priority location.

With more than 17.000 islands, Indonesia has a unique position in regional and geopolitics and geoeconomics. This position is followed by inevitable numerous consequences such as security vulnerability[10]. Fortunately, Indonesia can manage strategic relationships which are so dynamic and increasingly complex. The possibly future threats will increase in terms of quality and quantity from almost every aspect of life as a direct impact of globalization. Indonesia must be more prepared in dealing with new challenges. The border areas have to be the most anticipated. The maritime vision is expected to fill the policy gap as three quarters of the Indonesian territory are sea frontiers. In this context, empowering the outer islands as strategic frontiers will determine the future of Indonesia.

\section{Conclusion}

Joko Widodo's administration has been create some significant changes in how Indonesia managing its border areas particularly in addressing inequalities with nonborder areas. Yet, it is still a long way to go. Domestics, regional and global challenges will always be there to be encountered. Some suggestions then can be delivered as consideration to improve the policy and implementation as follows:

1. Indonesia government should maximize the role of the border taskforce to routinely evaluate the condition of the society in the border areas.

2. Indonesia government should build more public facilities with high standard in each of strategic border areas.

3. Indonesia government has to synchronize all the specific functions both civil and military state apparatus proportionally.

4. The local government has to increase the quality of public service in the border areas.

5. Community development and empowerment must accommodate local values to encourage more engaging citizen participation in border development.

\section{References}

1. N. Suparman, D. Silvya \& A. Sudirman, "Regionalisme dalam Studi Hubungan Internasional", Yogyakarta: Pustaka Pelajar, pp. 32-33 (2010).

2. S.S. Hadiwijoyo, "Batas Wilayah Negara Indonesia, Dimensi, Permasalahan, dan Strategi Penanganan: Sebuah Tinjauan Empiris dan Yuridis", Gava Media, Yogyakarta(2009). 
3. A. Stilz, "Why do states have territorial rights?", International Theory, 1(2), pp. 185-213 (2009).

4. B. Buzan, et al., "Security: A New Framework for Analysis", Lynne Rienne, London, pp. 95-117 (1998). Retrieved from http://bnpp.go.id/index.php/kawasanperbatasan.

5. O.J. Martinez, "The Dynamics of Border Interaction: New Approaches to Border Analysis in C. H. Schofield (Ed)", Global Boundaries: World Boundaries Vol. 1, Routledge, London, p.6 (1994). Retrieved from https://www.bappenas.go.id/id/berita-dan-siaranpers/usul-perkuat-kemaritiman-dan kedaulatannegara/.
6. Pertamina, "Pertamina Kembali Realisasikan BBM Satu Harga di 9 Wilayah", Retrieved from http://www.pertamina.com/news-room/siaranpers/pertamina-kembali-realisasikan-bbm-satuharga-di-9-wilayah/ (2017).

7. E. Simorangkir, "Lewat Tol Laut, Jokowi Buka Jalur Ekonomi dari Barat ke Timur RI" Retrieved from https://finance.detik.com/berita-ekonomibisnis/3605640/lewat-tol-laut-jokowi-buka-jalurekonomi-dari-barat-ke-timur-r.i (2017).

8. T. Allard, and B.C. Munthe, "Asserting sovereignty, Indonesia renames part of South China Sea", Retrieved from https://www.reuters.com/article/usindonesia-politics-map/asserting-sovereigntyindonesia-renames-part-of-south-china-seaidUSKBN19Z0YQ (2017).

*Corresponding author: rizkiar@hotmail.com 